\title{
Gastric Cancer pTis TNM Finding v6 and v7
}

National Cancer Institute

\section{Source}

National Cancer Institute. Gastric Cancer pT is TNM Finding v6 and v7. NCI Thesaurus.

Code C61183.

Gastric cancer in situ with cancer cells confined within the glandular basement membrane (intraepithelial) and without invasion into the lamina propria. (from AJCC 6th and 7th Eds.) 